\title{
STUDI TENTANG MUTU BATAKO YANG ADA DI PASARAN WILAYAH JAKARTA TIMUR TERHADAP SNI 03-0349-1989
}

\author{
Munawaroh, Ir. Erna Septiandini, MT, Dra. Nira Nasution, M.Pd
}

\begin{abstract}
Abstrak
Penelitian ini bertujuan untuk menganalisa mutu suatu bahan bangunan yaitu Batako. Banyaknya batako yang bersedar di pasaran dan tidak adanya kontrol terhadap kualitas/mutu batako oleh produsen, merupakan salah satu faktor yang menyebabkan Batako tidak memenuhi standar (SNI 03-0349-1989). Dalam penelitian ini ada 9 kelompok Batako yang diambil langsung dari pabrik/produsen Batako, dengan pertimbangan bahwa 9 kelompok tersebut dapat mewakili wilayah tertentu. Metode penelitian yang digunakan adalah metode eksperimen dan deskriptif. Sebagai acuan yang berlaku di Indonesia menggunakan Standar Nasional Indonesia (SNI) 03-0349-1989.
\end{abstract}

Dari hasil penelitian yang telah dilaksanakan, ternyata batako yang diuji tidak memenuhi syarat mutu SNI 03-0349-1989. Pada pengujian sifat tampak masih banyak contoh batako yang bidang permukaannya cacat, rusuk-rusuknya tidak siku satu terhadap yang lainnya, sudut rusuknya mudah dirapihkan dengan kekuatan jari tangan sementara persyaratan pada sifat tampak dalam SNI 030349-1989 adalah bidang permukaan batako tidak boleh cacat, rusuk-rusuk batako siku satu terhadap yang lainnya, sudut rusuk batako tidak mudah dirapihkan dengan kekuatan jari tangan.

Hasil pengujian sifat tampak kelompok $A, B, C, E, F, I$ memenuhi SNI 03-03491989, sedangkan kelompok $D, G, H$ tidak memenuhi memenuhi SNI 03-03491989. Pada pengujian ukuran ternyata kelompok $A, B, C, D, E, F, H$, dan I untuk ukuran panjang, lebar, dan tebalnya tidak memenuhi toleransi SNI 03-0349-1989 yaitu untuk panjangnya minimum $38,5 \mathrm{~cm}$ dan maksimum $39,5 \mathrm{~cm}$; lebarnya minimum $18,5 \mathrm{~cm}$ dan maksimum $19,3 \mathrm{~cm}$; tebalnya minimum $9,8 \mathrm{~cm}$ dan maksimum 10,2 cm. Hanya kelompok $G$ yang ukuran panjangnya memenuhi toleransi yaitu $39,1 \mathrm{~cm}$, sedangkan lebar dan tebalnya tidak memenuhi. Pada pengujian tebal dinding sekatan lubang semua contoh batako memenuhi SNI 030349-1989. Pada pengujian kuat tekan semua kelompok tidak memenuhi nilai minimum SNI 03-0349-1989 yaitu $20 \mathrm{~kg} / \mathrm{cm} 2$. Pada pengujian penyerapan air semua kelompok memenuhi SNI 03-0349-1989 yaitu maksimum 25 \% (tingkat mutu l). 


\section{PENDAHULUAN}

Seiring pertambahan jumlah penduduk di Indonesia yang semakin pesat maka program pembangunan fisik seperti perumahan dan sarana prasarana juga meningkat. Seperti yang terjadi di kota Jakarta saat ini banyak didirikan gedung-gedung perkantoran, apartemen, mall, rumah susun dengan program pembangunan 1000 tower, komplek perumahan mewah sampai komplek perumahan sederhana.

Dengan adanya pembangunan fisik yang meningkat maka kebutuhan bahan bangunan menjadi meningkat, sehingga memberikan kesempatan kepada para produsen menciptakan berbagai jenis bahan bangunan dengan berbagai macam tipe, bentuk, kualitas, dan harga. Misalnya saja bahan bangunan untuk dinding atau pemisah ruangan ada berbagai macam pilihan seperti batu bata, batako, hebel, dan dinding panel.

Untuk elemen dinding selain bata merah, batako merupakan bahan bangunan yang biasa digunakan untuk pasangan dinding. Karena batako memiliki kelebihan yaitu pemasangannya relatif cepat dan harganya relatif murah, sehingga dapat mengurangi biaya dan mempercepat waktu penyelesaian pembangunan. Dengan meningkatnya pembangunan sarana fisik seperti gedung-gedung perkantoran, mall, aparteman, rumah susun dan harganya yang relatif murah sehingga terjangkau oleh masyarakat maka permintaan pasokan batako semakin meningkat.

Seiring meningkatnya permintaan batako, usaha batako kini semakin menjamur sehingga antar produsen bersaing untuk menjual dengan harga yang murah, apakah hal ini tidak mempengaruhi kualitas batako ? Selain itu permintaan pasokan batako yang besar menyebabkan produsen memproduksi batako dalam jumlah yang besar. Berdasarkan wawancara peneliti disalah satu tempat produksi batako, untuk mengejar target dan memenuhi pasokan batako di pasaran dalam waktu satu hari harus menghasilkan kurang lebih 6000 batako dengan menggunakan empat mesin press.

Meskipun produsen harus memproduksi batako dalam jumlah yang besar karena banyaknya permintaan batako di pasaran, tetapi kualitas mutu batako yang diproduksi harus tetap dijaga agar memenuhi standar. Karena salah satu faktor yang menentukan kualitas suatu bangunan 
adalah kualitas atau mutu bahan pembentuknya dalam hal ini adalah bahan bangunan batako. Namun sering dijumpai di lapangan ada batako yang permukaannya cacat atau retak-retak, rusuk-rusuknya tidak tajam karena mengalami kerusakan, mudah hancur, dan jika dipegang butiran-butiran penyusun batako mudah terlepas. Hal ini menunjukkan mutu batako yang di produksi belum memenuhi standar.

Hasil produksi batako sebelum dipasarkan harus menjalani pengujian untuk mengontrol kualitas atau mutu batako. Dalam hal ini Badan Standardisasi Nasional (BSN) telah mengeluarkan standar yang membahas tentang syarat mutu dan cara pengujian mutu batako yaitu SNI 030349-1989. Syarat mutu batako meliputi pandangan luar, ukuran dan toleransi, kuat tekan dan penyerapan air. Dengan adanya SNI tersebut apakah mutu batako yang ada di pasaran sudah memenuhi standar yang tertera di SNI 03-0349-1989?.

Berdasarkan hal tersebut, maka batako yang ada di pasaran dianalisis dan diuji mutunya. Contoh batako yang diuji diambil dari pabrik/produsen batako yang mendistribusikan hasil produksinya ke toko-toko material yang ada di wilayah Jakarta Timur. Pengujian batako meliputi pandangan luar (sifat tampak), ukuran dan toleransi, kuat tekan dan penyerapan air.

Dengan memperhatikan latar belakang masalah di atas, maka diidentifikasi masalah-masalah yang ada sebagai berikut :

1. Apakah batako yang ada di pasaran wilayah Jakarta Timur memenuhi syarat SNI 030349-1989?

2. Bagaimana hasil analisis mutu batako terhadap SNI 03-0349-1989?

3. Berapa persenkah penyimpangan mutu batako terhadap SNI 03-0349-1989 jika terjadi penyimpangan?

4. Apakah SNI 03-0349-1989 menjadi acuan dalam proses pembuatan batako?

Pembatasan masalah dari penelitian ini adalah :

1. Bahan yang digunakan dalam penelitian adalah batako berlobang.

2. Batako yang diambil untuk diuji berasal dari pabrik batako yang mendistribusikan hasil produksinya ke toko-toko material yang ada di wilayah Jakarta Timur.

3. Standar acuan yang digunakan adalah SNI 03-0349-1989. 


\section{METODA}

\section{Pengertian Batako}

Menurut Supribadi (1987) batako dapat dikatakan semacam batu cetak yang terbuat dari campuran tras tambah kapur dan air atau dapat juga dibuat dengan campuran semen tambah kapur tambah pasir dan ditambah air, yang dalam keadaan lekat dicetak menjadi balok-balok dengan ukuran tertentu, dimana proses pengerasannya tanpa melalui pembakaran. Pengertian batako menurut Standar Nasional Indonesia (SNI) 03-0349-1989. Bata beton adalah suatu jenis unsur bangunan yang dibuat dari bahan utama semen portland, air dan agregat yang dipergunakan untuk pasangan dinding.

\section{Syarat Mutu Batako (SNI 03-0349-1989)}

\section{Pandangan Luar (sifat tampak)}

Bidang permukaannya harus tidak cacat. Bentuk permukaan lain yang didesain diperbolehkan. Rusuk-rusuknya siku satu terhadap yang lain, dan sudut rusuknya tidak mudah dirapihkan dengan kekuatan jari tangan.

\section{Ukuran dan Toleransi}

Ukuran batako harus sesuai dengan tabel 1

Tabel.1 Ukuran Batako menurut SNI 03-0349-1989

\begin{tabular}{|l|l|l|l|l|l|}
\hline \multirow{2}{*}{ Jenis } & \multicolumn{3}{|l|}{ Ukuran $(\mathrm{mm})$} & \multicolumn{2}{l|}{ Tebal dinding sekatan lobang minimum } \\
\cline { 2 - 6 } & Pajang & Lebar & Tebal & Luar & Dalam \\
\hline Pejal & $390+3$ & $90 \pm 2$ & $100 \pm 2$ & - & - \\
Berlobang & 5 & & & & \\
Kecil & $390+3$ & $190+3$ & $100 \pm 2$ & 20 & 15 \\
Besar & 5 & 5 & & & 20 \\
& $390+3$ & $190+3$ & $200 \pm 2$ & 25 & 20 \\
\hline
\end{tabular}

Sumber : SNI 03-0349-1989, Badan Standardisasi Nasional

\section{Syarat Fisis (kuat tekan dan penyerapan air)}

Batako harus memenuhi syarat-syarat fisis sesuai dengan tabel 2. 
Tabel.2 Syarat-syarat fisis batako menurut SNI 03-0349-1989

\begin{tabular}{|c|c|c|c|c|c|c|c|c|c|}
\hline \multirow[t]{2}{*}{ Syarat fisis } & \multirow[t]{2}{*}{ Satuan } & \multicolumn{4}{|c|}{$\begin{array}{l}\text { Tingkat mutu batako } \\
\text { pejal }\end{array}$} & \multicolumn{4}{|c|}{$\begin{array}{l}\text { Tingkat mutu batako } \\
\text { berlobang }\end{array}$} \\
\hline & & I & II & III & IV & I & II & III & IV \\
\hline $\begin{array}{l}\text { 1. Kuat tekan bruto } \\
\text { rata-rata minimum }\end{array}$ & $\mathrm{kg} / \mathrm{cm}^{2}$ & 100 & 70 & 40 & 25 & 70 & 50 & 35 & 20 \\
\hline $\begin{array}{l}\text { 2. Kuat tekan bruto } \\
\text { masing-masing } \\
\text { benda uji }\end{array}$ & $\mathrm{kg} / \mathrm{cm}^{2}$ & 90 & 65 & 35 & 21 & 65 & 45 & 30 & 17 \\
\hline $\begin{array}{l}\text { 3. Penyerapan air rata- } \\
\text { rata, maksimum }\end{array}$ & $\%$ & 25 & 35 & - & - & 25 & 35 & - & - \\
\hline
\end{tabular}

Kuat tekan bruto adalah beban tekan keseluruhan pada waktu benda coba pecah, dibagi dengan luas ukuran nyata dari bata termasuk luas lubang serta cekungan tepi.

Batako adalah suatu jenis unsur bangunan yang dibuat dari bahan utama semen portland, air dan agregat yang dipergunakan untuk pasangan dinding. Batako termasuk batu buatan yang tidak di bakar, kekerasannya tergantung dari kualitas bahan susun, perbandingan campuran dan kemampatannya pada proses pencetakannya. Selain batu bata, batako merupakan bahan bangunan yang biasa digunakan untuk pasangan dinding, karena batako mempunyai kelebihan yaitu harganya relatif lebih murah dan pemasangannya lebih cepat.

Usaha batako kini semakin menjamur sehingga antar produsen bersaing untuk menjual dengan harga yang murah. Hal ini akan mempengaruhi kualitas mutu batako. Kualitas atau mutu batako yang beredar di pasaran harus tetap diperhatikan agar memenuhi standar. Karena salah satu faktor yang menentukan kualitas suatu bangunan adalah kualitas atau mutu bahan pembentuknya dalam hal ini adalah bahan bangunan batako. Hasil produksi batako sebelum dipasarkan harus menjalani pengujian mutu sesuai standar yaitu SNI 03-0349-1989 yang meliputi : (a) Pengujian pandangan luar atau tampak luar (b) ukuran dan toleransi (c) Pengujian kuat tekan (d) pengujian daya serap. Sering dijumpai di pasaran ada batako yang tidak memenuhi standar. Hal ini dapat diamati dari tampak luarnya yaitu bidang permukaannya cacat atau retak-retak, rusuk-rusuknya tidak tajam karena mengalami kerusakan, mudah hancur, dan jika dipegang butiran-butiran penyusun batako mudah terlepas. Produksi batako sebelum dipasarkan tidak dilakukan pengecekan mutu batako oleh produsen/pelaku usaha yang mengacu pada SNI. Hal ini disebabkan karena ketidaktahuan tentang syarat mutu batako sesuai SNI dan 
tidak adanya peralatan pengujian yang memadai karena produksi batako didominasi oleh industri kecil.

Dari kerangka berpikir di atas, maka dapat dirumuskan hipotesis sebagai berikut : Batako berlobang yang beredar di pasaran wilayah Jakarta Timur memenuhi syarat mutu SNI 03-03491989.

Syarat SNI 03-0349-1989 di atas meliputi :

1. Pandangan luar batako (sifat tampak).

2. Ukuran dan toleransi.

3. Kuat tekan.

4. Penyerapan air.

\section{HASIL DAN PEMBAHASAN}

Berdasarkan hasil penelitian yang telah dilakukan terhadap benda uji batako yang beredar di wilayah Jakarta Timur, yaitu penelitian dilakukan mulai dari pandangan luar (sifat tampak), ukuran dan toleransi, kuat tekan dan penyerapan air yang sesuai dengan SNI 03-0349-1989 maka dapat dideskriptifkan sebagai berikut:

\section{Deskripsi Data}

\section{Persiapan Benda Uji}

Bahan yang digunakan pada penelitian ini adalah batako yang beredar di pasaran wilayah Jakarta Timur, Benda uji diambil langsung dari pabrik/produsen batako yang mendistribusikan hasil produksinya ke toko-toko material yang ada di kecamatan-kecamatan Jakarta Timur,

\section{Hasil Survey Lapangan}

Berdasarkan hasil Survey lapangan yang dilakukan pada bulan November 2010-Juni 2010, maka terdapat 9 pabrik/produsen batako yang mensuplay hasil produksinya ke toko-toko material yang ada di kecamatan-kecamatan di wilayah Jakarta Timur, Sampel yang diambil akan diuji kesesuaiannya terhadap SNI 03-0349-1989, Dari masing-masing kelompok/tiap produsen batako diambil 15 benda uji, Jadi benda uji keseluruhannya ada 135 buah, 
Tabel 3 Hasil Survey Pabrik Batako

\begin{tabular}{|c|c|c|c|}
\hline No & Nama Pabrik Batako & Alamat Pabrik Batako & $\begin{array}{c}\text { Kecamatan-Kecamatan } \\
\text { di Jakarta Timur }\end{array}$ \\
\hline 1 & $\begin{array}{l}\text { PT, Lima Benua } \\
\text { Multindo }\end{array}$ & $\begin{array}{l}\text { Jl, Mangun Jaya Tambun- } \\
\text { Bekasi }\end{array}$ & Matraman \\
\hline 2 & Kokoh Block Jaya & Kp, Kebon Jajelan Bekasi & Duren Sawit \\
\hline 3 & PT, Hardy & $\begin{array}{l}\text { Jl, Raya Kebalen, Babelan- } \\
\text { Bekasi }\end{array}$ & Makasar \\
\hline 4 & $\begin{array}{l}\text { PT, Cipta Sejahtera } \\
\text { Nusantara }\end{array}$ & $\begin{array}{l}\text { Jl Raya Kebalen No,11, } \\
\text { Babelan-Bekasi }\end{array}$ & Jatinegara \\
\hline 5 & PD, Langgeng & Jl, Raya Perjuangan, Bekasi & Ciracas \\
\hline 6 & Utama Jaya & $\begin{array}{l}\text { Jl, Raya Pasar Rebo No,56, } \\
\text { Jaka Setia-Bekasi }\end{array}$ & Kramatjati, Pasar rebo \\
\hline 7 & HRS & $\begin{array}{l}\text { Jl, Raya Kodau Jatimekar, } \\
\text { Jatiasih-Bekasi }\end{array}$ & Cakung \\
\hline 8 & Cendana Timber & $\begin{array}{l}\text { Jalan Raya Jatiwarna No, } 10 \\
\text { Pondok Gede Bekasi }\end{array}$ & Cipayung \\
\hline 9 & PD, Mandiri Sukses & $\begin{array}{l}\text { Jl, Teluk Pucung Kec, Bekasi } \\
\text { Utara }\end{array}$ & Pulogadung \\
\hline
\end{tabular}

\section{Pengujian Mutu Batako}

Tabel 4. Tabel Sampel Benda Uji

\begin{tabular}{|c|c|c|c|}
\hline No & Kelompok & $\begin{array}{c}\text { Kecamatan-kecamatan di } \\
\text { Jakarta Timur }\end{array}$ & $\begin{array}{c}\text { Jumlah sampel } \\
\text { tiap kelompok }\end{array}$ \\
\hline 1, & A & Matraman & 10 \\
\hline 2, & B & Duren Sawit & 10 \\
\hline 3, & C & Makasar & 10 \\
\hline 4, & D & Jatinegara & 10 \\
\hline 5, & E & Ciracas & 10 \\
\hline 6, & F & Kramat Jati, Pasar rebo & 10 \\
\hline 7, & G & Cakung & 10 \\
\hline 8, & H & Cipayung & 10 \\
\hline 9, & I & Pulogadung & 10 \\
\hline \multicolumn{2}{|r|}{ Total Jumlah Sampel } & 90 \\
\hline
\end{tabular}


Setelah menentukan sampel, maka peneliti segera melakukan pengambilan benda uji, Setelah benda uji siap, dilakukan pengujian yang meliputi pandangan luar, ukuran dan toleransi, kuat tekan dan penyerapan air, Sebelum di uji masing-masing sampel diberi tanda dengan ketentuan untuk mewakili asal pabrik dan wilayah menggunakan simbol $A, B, C, D, E, F, G, H$, dan I, Seperti yang disajikan dalam Tabel 4

\section{Hasil Pengujian}

Hasil pengujian disajikan dalam bentuk tabel berikut :

\section{Hasil Uji Pandangan Luar (Sifat Tampak)}

Tabel 5 Hasil Pengujian sifat Tampak (Permukaan Batako Tidak boleh cacat)

\begin{tabular}{|c|c|c|c|c|c|c|}
\hline \multirow{2}{*}{$\begin{array}{l}\text { Kelompok } \\
\text { Benda Uji }\end{array}$} & \multicolumn{5}{|c|}{ Sampel Benda UJi } & \multirow{2}{*}{ keterangan } \\
\hline & 1 & 2 & 3 & 4 & 5 & \\
\hline A & Tidak Cacat & Cacat & Tidak Cacat & Cacat & Tidak Cacat & Lulus Uji \\
\hline B & Cacat & Cacat & Tidak Cacat & Tidak Cacat & Tidak Cacat & Lulus Uji \\
\hline $\mathrm{C}$ & Tidak Cacat & Tidak Cacat & Cacat & Cacat & Tidak Cacat & Lulus Uji \\
\hline $\mathrm{D}$ & Tidak Cacat & Cacat & Tidak Cacat & Cacat & Cacat & Lulus Uji \\
\hline E & Cacat & Tidak Cacat & Cacat & Tidak Cacat & Tidak Cacat & Lulus Uji \\
\hline $\mathrm{F}$ & Cacat & Tidak Cacat & Tidak Cacat & Cacat & Tidak Cacat & Lulus Uji \\
\hline G & Cacat & Cacat & Cacat & Cacat & Cacat & Tidak Lulus Uji \\
\hline $\mathrm{H}$ & Cacat & Tidak Cacat & Tidak Cacat & Cacat & Tidak Cacat & Lulus Uji \\
\hline I & Tidak Cacat & Tidak Cacat & Cacat & Tidak Cacat & Cacat & Lulus Uji \\
\hline
\end{tabular}

Tabel 6 Hasil Pengujian Sifat Tampak (Rusuk-rusuk batako siku satu terhadap yang lainnya)

\begin{tabular}{|c|c|c|c|c|c|c|}
\hline \multirow{2}{*}{$\begin{array}{c}\text { Kelompok } \\
\text { Benda Uji }\end{array}$} & \multicolumn{5}{|c|}{ Sampel Benda UJi } & \multirow{2}{*}{ Keterangan } \\
\cline { 2 - 6 } & $\mathbf{1}$ & $\mathbf{2}$ & $\mathbf{3}$ & $\mathbf{4}$ & $\mathbf{5}$ & \\
\hline A & Siku & Siku & Siku & Siku & Siku & Lulus Uji \\
\hline B & Siku & Siku & Siku & Siku & Siku & Lulus Uji \\
\hline C & Siku & Siku & Siku & Siku & Siku & Lulus Uji \\
\hline D & Tidak siku & Siku & Siku & Tidak siku & Siku & Lulus Uji \\
\hline E & siku & Tidak siku & Siku & Siku & Siku & Lulus Uji \\
\hline F & Tidak siku & Tidak siku & Tidak siku & siku & Tidak siku & Lulus Uji \\
\hline G & Tidak siku & siku & Tidak siku & Tidak siku & siku & Lulus Uji \\
\hline H & Tidak siku & Tidak siku & siku & siku & siku & Lulus Uji \\
\hline I & siku & Tidak siku & Tidak siku & siku & Tidak siku & Lulus Uji \\
\hline
\end{tabular}


Tabel 7 Hasil Pengujian Sifat Tampak (sudut rusuk batako yang tidak mudah dirapihkan dengan kekuatan jari tangan)

\begin{tabular}{|c|c|c|c|c|c|c|}
\hline A & Tidak Mudah & Mudah & Tidak Mudah & Tidak Mudah & Tidak Mudah & Lulus Uji \\
\hline B & Tidak Mudah & Mudah & Tidak Mudah & Tidak Mudah & Tidak Mudah & Lulus Uji \\
\hline C & Tidak Mudah & Tidak Mudah & Mudah & Mudah & Tidak Mudah & Lulus Uji \\
\hline D & Mudah & Mudah & Mudah & Mudah & Mudah & Tidak Lulus Uji \\
\hline E & Tidak Mudah & Tidak Mudah & Tidak Mudah & Tidak Mudah & Tidak Mudah & Lulus Uji \\
\hline F & Tidak Mudah & Tidak Mudah & Tidak Mudah & Tidak Mudah & Tidak Mudah & Lulus Uji \\
\hline G & Mudah & Mudah & Tidak Mudah & Mudah & Tidak Mudah & Lulus Uji \\
\hline H & Mudah & Mudah & Mudah & Mudah & Mudah & Tidak Lulus Uji \\
\hline I & Tidak Mudah & Tidak Mudah & Mudah & Mudah & Mudah & Lulus Uji \\
\hline
\end{tabular}




\subsubsection{Hasil Uji Ukuran Dan Toleransi}

\section{Hasil Uji Ukuran dan Toleransi}

Tabel 4,6 Kesesuaian dan Persentase (\%) Penyimpangan Ukuran Rata-rata Tiap Kelompok Terhadap SNI

\begin{tabular}{|c|c|c|c|c|c|c|c|c|c|}
\hline $\begin{array}{l}\text { Kelompok } \\
\text { benda uji }\end{array}$ & $\begin{array}{l}\text { Rata- } \\
\text { rata } \\
\text { panjang } \\
(\mathbf{c m})\end{array}$ & $\begin{array}{c}\text { Kesesuaian } \\
\text { panjang } \\
\text { batako } \\
\text { terhadap SNI }\end{array}$ & $\begin{array}{l}\text { Persentase } \\
(\%) \\
\text { penyimpang } \\
\text { an panjang } \\
(\mathrm{cm})\end{array}$ & $\begin{array}{l}\text { Rata- } \\
\text { rata } \\
\text { lebar } \\
(\mathrm{cm})\end{array}$ & $\begin{array}{c}\text { Kesesuaian } \\
\text { lebar } \\
\text { batako } \\
\text { terhadap } \\
\text { SNI }\end{array}$ & $\begin{array}{c}\text { Persentase } \\
(\%) \\
\text { penyimpangan } \\
\text { lebar }\end{array}$ & $\begin{array}{l}\text { Rata- } \\
\text { rata } \\
\text { tebal } \\
(\mathrm{cm})\end{array}$ & $\begin{array}{c}\text { Kesesuaian } \\
\text { tebal } \\
\text { batako } \\
\text { terhadap } \\
\text { SNI }\end{array}$ & $\begin{array}{c}\text { Persentase } \\
(\%) \\
\text { penyimpangan } \\
\text { tebal }\end{array}$ \\
\hline A & 38,10 & $\begin{array}{c}\text { Tidak } \\
\text { memenuhi }\end{array}$ & 1,04 & 17,21 & $\begin{array}{c}\text { Tidak } \\
\text { memenuhi }\end{array}$ & 6,97 & 7,88 & $\begin{array}{c}\text { Tidak } \\
\text { memenuhi }\end{array}$ & 19,59 \\
\hline B & 37,61 & $\begin{array}{c}\text { Tidak } \\
\text { memenuhi }\end{array}$ & 2,31 & 17,43 & $\begin{array}{c}\text { Tidak } \\
\text { memenuhi }\end{array}$ & 5,78 & 7,69 & $\begin{array}{c}\text { Tidak } \\
\text { memenuhi }\end{array}$ & 21,53 \\
\hline $\mathrm{C}$ & 37,33 & $\begin{array}{c}\text { Tidak } \\
\text { memenuhi }\end{array}$ & 3,04 & 17,77 & $\begin{array}{c}\text { Tidak } \\
\text { memenuhi }\end{array}$ & 3,95 & 7,31 & $\begin{array}{c}\text { Tidak } \\
\text { memenuhi }\end{array}$ & 25,41 \\
\hline $\mathrm{D}$ & 37,37 & $\begin{array}{c}\text { Tidak } \\
\text { memenuhi }\end{array}$ & 3,04 & 17,80 & $\begin{array}{c}\text { Tidak } \\
\text { memenuhi }\end{array}$ & 3,78 & 7,92 & $\begin{array}{c}\text { Tidak } \\
\text { memenuhi }\end{array}$ & 19,18 \\
\hline E & 38,09 & $\begin{array}{c}\text { Tidak } \\
\text { memenuhi }\end{array}$ & 1,06 & 17,60 & $\begin{array}{c}\text { Tidak } \\
\text { memenuhi }\end{array}$ & 4,86 & 7,94 & $\begin{array}{c}\text { Tidak } \\
\text { memenuhi }\end{array}$ & 18,98 \\
\hline $\mathrm{F}$ & 37,15 & $\begin{array}{c}\text { Tidak } \\
\text { memenuhi }\end{array}$ & 3,51 & 15,34 & $\begin{array}{c}\text { Tidak } \\
\text { memenuhi }\end{array}$ & 17,08 & 7,54 & $\begin{array}{c}\text { Tidak } \\
\text { memenuhi }\end{array}$ & 23,06 \\
\hline $\mathrm{G}$ & 39,10 & Memenuhi & 0,00 & 14,96 & $\begin{array}{c}\text { Tidak } \\
\text { memenuhi }\end{array}$ & 19,14 & 9,16 & $\begin{array}{c}\text { Tidak } \\
\text { memenuhi }\end{array}$ & 6,53 \\
\hline $\mathrm{H}$ & 38,06 & $\begin{array}{c}\text { Tidak } \\
\text { memenuhi }\end{array}$ & 1,14 & 17,23 & $\begin{array}{c}\text { Tidak } \\
\text { memenuhi }\end{array}$ & 6,86 & 7,92 & $\begin{array}{c}\text { Tidak } \\
\text { memenuhi }\end{array}$ & 19,18 \\
\hline I & 37,15 & Tidak & 3,51 & 16,21 & Tidak & 12,38 & 7,58 & Tidak & 22,65 \\
\hline
\end{tabular}


Hasil Uji Tebal Dinding Sekatan Lobang

Tabel 9 Nilai Rata-rata dan Kesesuaian Tebal Dinding Sekatan Lobang Tiap Kelompok Terhadap SN1

\begin{tabular}{|c|c|c|c|c|}
\hline $\begin{array}{c}\text { Kelompok } \\
\text { benda uji }\end{array}$ & $\begin{array}{c}\text { Tebal dinding } \\
\text { sekatan } \\
\text { lobang luar } \\
\text { (cm) }\end{array}$ & $\begin{array}{c}\text { Kesesuaian tebal } \\
\text { dinding sekatan } \\
\text { lobang luar } \\
\text { terhadap SNI }\end{array}$ & $\begin{array}{c}\text { Tebal dinding } \\
\text { sekatan } \\
\text { lobang dalam } \\
\text { (cm) }\end{array}$ & $\begin{array}{c}\text { Kesesuaian tebal } \\
\text { dinding sekatan } \\
\text { lobang dalam } \\
\text { terhadap SNI }\end{array}$ \\
\hline A & 2,1 & Memenuhi & 2,7 & Memenuhi \\
\hline B & 2,2 & Memenuhi & 2,5 & Memenuhi \\
\hline C & 2,2 & Memenuhi & 2,6 & Memenuhi \\
\hline D & 2,2 & Memenuhi & 2,7 & Memenuhi \\
\hline E & 2,3 & Memenuhi & 2,2 & Memenuhi \\
\hline F & 2,2 & Memenuhi & 2,3 & Memenuhi \\
\hline G & 2,4 & Memenuhi & 2,7 & Memenuhi \\
\hline H & 2,3 & Memenuhi & 2,8 & Memenuhi \\
\hline I & 2,2 & Memenuhi & 2,7 & Memenuhi \\
\hline SNI & Minimum 20 mm $(2 \mathrm{~cm})$ & Minimum 15 mm $(1,5$ cm $)$ \\
\hline
\end{tabular}

Hasil Pengujian Jenis Batako

Hasil Uji Luas Lubang Batako

Tabel 10. Persentase (\%) Luas Lubang Batako

\begin{tabular}{|c|c|c|c|c|c|}
\hline \multirow{2}{*}{$\begin{array}{c}\text { Kelompok } \\
\text { Benda Uji }\end{array}$} & \multicolumn{5}{|c|}{ Sampel Benda UJi (\%) } \\
\cline { 2 - 6 } & $\mathbf{1}$ & $\mathbf{2}$ & $\mathbf{3}$ & $\mathbf{4}$ & $\mathbf{5}$ \\
\hline A & 37,52 & 38,32 & 37,34 & 37,60 & 37,25 \\
\hline B & 38,89 & 38,75 & 38,59 & 38,17 & 38,46 \\
\hline C & 33,24 & 33,03 & 32,28 & 32,21 & 33,56 \\
\hline D & 33,28 & 34,28 & 33,23 & 33,52 & 34,58 \\
\hline E & 35,43 & 35,97 & 34,99 & 35,91 & 35,46 \\
\hline F & 32,48 & 30,91 & 30,88 & 32,89 & 32,40 \\
\hline G & 29,72 & 29,96 & 29,82 & 29,29 & 29,95 \\
\hline H & 31,59 & 32,03 & 32,00 & 31,73 & 31,06 \\
\hline I & 33,09 & 32,66 & 33,40 & 33,53 & 33,82 \\
\hline
\end{tabular}


Hasil Uji Volume Lubang Batako

Tabel 11 Persentase (\%) Volume Lubang Batako

\begin{tabular}{|c|c|c|c|}
\hline \multirow{2}{*}{ Kelompok } & \multicolumn{3}{|c|}{ Sampel Benda UJi (\%) } \\
\cline { 2 - 4 } & $\mathbf{1}$ & $\mathbf{2}$ & $\mathbf{3}$ \\
\hline A & 35,01 & 35,26 & 33,90 \\
\hline B & 33,89 & 34,14 & 32,87 \\
\hline C & 29,62 & 28,09 & 29,34 \\
\hline D & 28,72 & 28,35 & 29,05 \\
\hline E & 28,36 & 29,46 & 28,30 \\
\hline F & 31,50 & 30,87 & 30,99 \\
\hline G & 25,45 & 25,89 & 26,41 \\
\hline H & 27,62 & 27,99 & 27,31 \\
\hline I & 31,50 & 31,55 & 32,53 \\
\hline
\end{tabular}

\section{Hasil Uji Kuat Tekan}

Tabel 12 Nilai Rata-rata Kuat Tekan Batako dan Persentase (\%) Penyimpangan Terhadap SNI

\begin{tabular}{|c|c|c|c|}
\hline $\begin{array}{c}\text { 4.Refomplok } \\
\text { bendąuji }\end{array}$ & $\begin{array}{l}\text { Nilai kuat tekan rata- } \\
\text { rata dari } 5 \text { buah } \\
\text { benda uji } \\
\left(\mathrm{kg} / \mathrm{cm}^{2}\right)\end{array}$ & $\begin{array}{l}\text { Kesesuaian nilai } \\
\text { kuat tekan terhadap } \\
\text { SNI }\end{array}$ & $\begin{array}{l}\text { Persentase (\%) } \\
\text { Penyimpangan } \\
\text { nilai kuat tekan }\end{array}$ \\
\hline$A^{s}$ & 5,76 & Tidak memenuhi & 71,22 \\
\hline$B^{1}$ & 7,53 & Tidak memenuhi & 62,34 \\
\hline $\mathrm{C}$ & 10,48 & Tidak memenuhi & 47,60 \\
\hline $\mathrm{D}_{\mathbf{U}}$ & 3,36 & Tidak memenuhi & 83,22 \\
\hline$E$. & 11,08 & Tidak memenuhi & 44,58 \\
\hline $\mathrm{F}^{+}$ & 11,28 & Tidak memenuhi & 43,58 \\
\hline G & 9,06 & Tidak memenuhi & 54,68 \\
\hline $\mathrm{H}_{\mathbf{P}}$ & 3,54 & Tidak memenuhi & 82,29 \\
\hline 1 & 4,89 & Tidak memenuhi & 75,53 \\
\hline SNI & \multicolumn{3}{|c|}{ Nilai kuat tekan rata-rata min $20 \mathrm{~kg} / \mathrm{cm}^{2}$} \\
\hline
\end{tabular}




\section{Penyerapan Air}

Tabel 13 Nilai Rata-rata Penyerapan Air Tiap Kelompok

\begin{tabular}{|c|c|}
\hline $\begin{array}{c}\text { Kelompok } \\
\text { benda uji }\end{array}$ & Penyerapan air rata-rata $(\%)$ \\
\hline A & 15,04 \\
\hline B & 13,00 \\
\hline C & 15,88 \\
\hline D & 16,47 \\
\hline E & 12,72 \\
\hline F & 14,27 \\
\hline G & 13,78 \\
\hline H & 20,76 \\
\hline I & 12,32 \\
\hline
\end{tabular}

\section{KESIMPULAN}

Dari hasil penelitian maka dapat disimpulkan bahwa :

1. Berdasarkan SNI 03-0349-1989, syarat mutu batako pada pandangan luar (sifat tampak) adalah bidang permukaan batako tidak boleh cacat, rusuk-rusuknya siku satu terhadap yang lain, dan sudut rusuknya tidak mudah dirapihkan dengan kekuatan jari tangan. Hasil analisis Dari ketiga pengujian sifat tampak tersebut disimpulkan kelompok A, B, C, E, F, I memenuhi SNI 03-0349-1989, sedangkan kelompok D, G, H tidak memenuhi memenuhi SNI 03-0349-1989.

2. Berdasarkan tabel ukuran SNI 03-0349-1989 hasil analisa ukuran dan toleransi, maka kelompok A, B, C, D, E, F, H, I untuk ukuran panjang, lebar, dan tebalnya tidak memenuhi ukuran dan toleransi. Kelompok $\mathrm{G}$ untuk panjangnya memenuhi ukuran dan toleransi SNI 03-0349-1989, sedangkan untuk ukuran lebar dan tebalnya tidak memenuhi toleransi.

3. Hasil analisa uji definisi, kelompok $A, B, C, D, E, F, G, H, I$ memenuhi persyaratan bata beton berlubang. Karena hasil uji luas penampang lubang kelompok A, B, C, D, E, F, G, $\mathrm{H}$, I lebih dari $25 \%$ luas penampang bata dan volume lubang lebih dari $25 \%$ volume bata seluruhnya. Sesuai dengan definisi bata beton berlubang menurut SNI 03-0349- 
1989 yaitu bata beton berlubang adalah bata yang memiliki luas penampang lubang lebih dari $25 \%$ luas penampang batanya dan volume lubang lebih dari $25 \%$ volume bata seluruhnya.

4. Hasil analisa untuk kuat tekan rata-rata semua kelompok benda uji tidak memenuhi kuat tekan minimal yang ditetapkan SNI 03-0349-1989 yaitu 20 kg/cm2.

5. Berdasarkan tabel syarat-syarat fisis SNI 03-0349-1989, hasil analisa penyerapan air, semua kelompok benda uji masuk ke dalam tingkat mutu I (kurang dari 25\%). 